Bull. Chem. Soc. Ethiop. 2021, 35(2), 229-241.

(c) 2021 Chemical Society of Ethiopia and The Authors

ISSN 1011-3924

DOI: https://dx.doi.org/10.4314/bcse.v35i2.2

Printed in Ethiopia

Online ISSN 1726-801X

\title{
EVALUATION OF RISK CAUSED BY INTAKE OF TRACE METAL THROUGH CONSUMPTION OF PLEUROTUS TUBER-REGIUM COLLECTED AROUND AUTOMOBILE VILLAGE IN ABIA STATE
}

\author{
Ukaogo Prince Onyedinma $^{1 *}$, Siddhant ${ }^{2}$, Ezeibe Chidi Nwaru ${ }^{3}$, Precious Onyinyechi Chukwu ${ }^{1}$, \\ Atem Bethel Ajong ${ }^{4}$ and Farouk Dehmchi ${ }^{5}$ \\ ${ }^{1}$ Analytical/Environmental Unit, Department of Pure and Industrial Chemistry, Abia State \\ University, Uturu, Nigeria \\ ${ }^{2}$ Department of Botany, Durgesh Nandini Degree College, Faizabad (U.P.), India \\ ${ }^{3}$ Department of Plant Science and Biotechnology, Abia State University, Uturu, Nigeria \\ ${ }^{4}$ Department of Biochemistry, Faculty of Sciences, University of Dschang, Dschang, Cameroon \\ ${ }^{5}$ Chemistry Department, Badji Mokhtar University, Annaba, Algeria
}

(Received October 29, 2020; Revised September 10, 2021; Accepted September 19, 2021)

\begin{abstract}
The bioaccumulation of trace metals in mushrooms poses a health risk to consumers. Despite the fact that mushroom eating has been linked to numerous health advantages, little attention has been paid to the relative health risks associated with trace metal build-up in this nutritional source in Nigeria. $\mathrm{Pb}, \mathrm{Cd}, \mathrm{Fe}, \mathrm{Hg}$ and As in Pleurotus tuber-regium collected from mechanic workshops in Umuahia were analysed and the associated health risks for the consumers were evaluated. The trace metal contents in the mushroom and its substrates showed a descending order of $\mathrm{Fe}>\mathrm{Pb}>\mathrm{Cd}>\mathrm{As}>\mathrm{Hg}$. The heavy metals concentration ranges in fruity body of the Pleurotus tuber-regium were $\mathrm{Fe}\left(62.16-98.17 \mathrm{mg} \mathrm{kg}^{-1}\right), \mathrm{Pb}\left(0.18-1.21 \mathrm{mg} \mathrm{kg}^{-1}\right), \mathrm{Cd}\left(0.05-0.34 \mathrm{mg} \mathrm{kg}^{-1}\right)$, As $\left(0.25-0.51 \mathrm{mg} \mathrm{kg}^{-1}\right)$ and $\mathrm{Hg}\left(0.009-0.021 \mathrm{mg} \mathrm{kg}^{-1}\right)$. The estimation of weekly intake values was lower than PTWIs of mushroom species except for Fe. According to the THQ and the HI calculations for trace metal contents in the mushrooms, mercury did not pose any risk on human health; whereas the other determined trace metals gave THQ values of $1<\mathrm{THQ}<10$ and showed the possibility of long-term risk.
\end{abstract}

KEY WORDS: Trace metals. Mushroom, Estimated weekly intake, Target hazard quotient, Bioaccumulation

\section{INTRODUCTION}

Mushroom is the fleshy, sponge-bearing fruiting body of a fungus, typically produced above the ground on soil or its food source. Apart from its medical values (for the treatment of rheumatism, kwashiorkor, obesity, diarrhoea and as a purgative), mushrooms have also been proven to be a good source of macromolecules (carbohydrates, proteins, fibers, lipids), and micronutrients (vitamins, and minerals) for the human body [1]

This very nutritional fungus (Pleurotus tuber-regium) has been found to develop or grow on natural substrates like logs of woods, decomposed agro- and animal wastes, and soil. These substrates generally have available nutrients which are externally digested and absorbed by the mycelium. Fungi, both edible and poisonous were and are used until now in traditional medicine largely in Asia and Central and Southern America of medicinal value [2], while apart from common knowledge on beneficial fiber, the clinical evidence is generally lacking [3]. The consumption of wild edible mushrooms is on the rise, mainly due to their taste, protein and trace mineral contents [4]. The past two to three decades have witnessed increasing publications evaluating the metal levels in foods and the environment at state and regional levels. Over the years, concern over the likelihood of human exposure to potentially toxic elements (PTE) from consumption has resulted in an array of publications many of which have reported low, moderate, or high bioaccumulation of certain trace elements by some mushroom species, including those widely consumed [5].

*Corresponding author. E-mail: prince.ukaogo@abiastateuniversity.edu.ng

This work is licensed under the Creative Commons Attribution 4.0 International License 
Pollution arising from the disposal of used lubricants is a widespread environmental problem in Nigeria and is gradually becoming worse than crude oil pollution [6]. In southeastern Nigeria, there are several other automobile workshops scattered all over the cities and villages from which used engine oils, lubricating oils and other solvents containing petroleum products are randomly dumped or spilt by artisans in the business of auto-repairs [7].

These unguided patterns have worsened the rate at which used engine oils spread and contaminate the soils and water around the cities. Spent lubricant or waste engine oil, is usually obtained after servicing and subsequently draining from automobile and generator engines [8]. Studies in auto repair workshop sites have been carried out by many researchers [9]. Nevertheless, most of them focused on the study of heavy metal contamination in soil by these used engine oils without recourse to the effects of polycyclic aromatic hydrocarbons (PAHs) present in used lubricants. Used lubricants easily migrate into the environment and eventually ooze into water bodies then to fungi [5].

The ecosystem pattern and physiology of mushroom species turn to determine the concentrations of metals them [10]. Certain metallic elements are accumulated in tissues and organs of living organisms in the food webs and an example is mercury [11]. For contaminants with a potential to build up in the body over time such as mercury, lead, and cadmium, the provisional tolerable weekly intake (PTWI) is used as reference values in evaluating the risks of intake of such toxic metals from food consumption. It has been reported that the accumulation of some elements in mushrooms is affected by environmental and fungal factors and this is well documented for mushrooms growing in soils polluted with $\mathrm{Hg}, \mathrm{Cd}, \mathrm{Pb}$, As or radioactive cesium [12]. The developmental stage of mushroom (fruit body) can also highly matter in view of exposure of the consumer for certain elements, e.g., radioactive cesium, while certain seem to be regulated by fungus and not change (decrease or increase), which can be relevant for specific consumers [13].

South-eastern Nigeria is a high rainfall area and boasts some of the wettest areas of the world. The high humidity of the area during the rainy season (April-September) provides ideal atmospheric conditions for the growth of many fungi, including edible Macromycetes [13]. During this period, people of this region usually harvest and consume mushrooms (over $15 \mathrm{~kg}$ yearly) and various species (Pleurotus tuber-regium, Auricularia auricular, Lentinus squarrosulus, etc) are displayed for sale along the major roads close to the harvest points. Only a few studies have reported the determination of many elements [5] and the evaluation of the bioaccumulation factor (BCF) of the elements in edible mushroom species native to various regions of Nigeria [15-17]. Although there are numerous studies carried out in various countries on minerals of edible wild-grown mushrooms including the impact of culinary processing and bioavailability [18-22] such studies are still very scarce in south-eastern Nigeria. The present study aimed to evaluate concentrations and bioaccumulation potential of $\mathrm{Fe}, \mathrm{As}, \mathrm{Cd}, \mathrm{Hg}$ and $\mathrm{Pb}$ by Pleurotus tuber-regium (fruiting bodies and substrate) collected around automobile village in Abia State, southeastern Nigeria. Also, the likely health risk from intake of potential toxic elements (PTE) from the mushroom consumption was evaluated by estimating weekly intakes and by comparing with provisional tolerable weekly intake (PTWI). To also assess the longterm potential health risks associated with metal intakes from consumption of the studied mushroom species, the target hazard quotients (THQ) and hazard index (HI) was calculated to evaluate the non-carcinogenic health risk. The findings of this study do not only add to the existing database on this subject matter but guide further investigations and provide a framework needed for the evaluation of the health risks associated with mushroom consumption.

\section{MATERIALS AND METHOD}

Description of the study areas

This study was carried out in Abia states in the southeast geopolitical zone of Nigeria, located within latitudes $4^{\circ} 15^{\prime} \mathrm{N}$ and $6^{\circ} 58^{\prime} \mathrm{N}$ longitude $6^{\circ} 50^{\prime} \mathrm{E}$ (Figure 1). Abia State has its capital

Bull. Chem. Soc. Ethiop. 2021, 35(2) 
territory at Umuahia. Aba one of the principal urban cities in Abia State is highly industrialized and also a commercial nerve centre of southeastern Nigeria. The population is essentially rural with farming and trading being their main occupations. The civil servants of this area prefer to reside mainly in urban centres [23]. Abia State is generally low lying with elevations rarely above 85 meters above sea level.The topography and physiography of these areas have been reported in literature [45]. Most of the sampled locations have well-developed road networks.

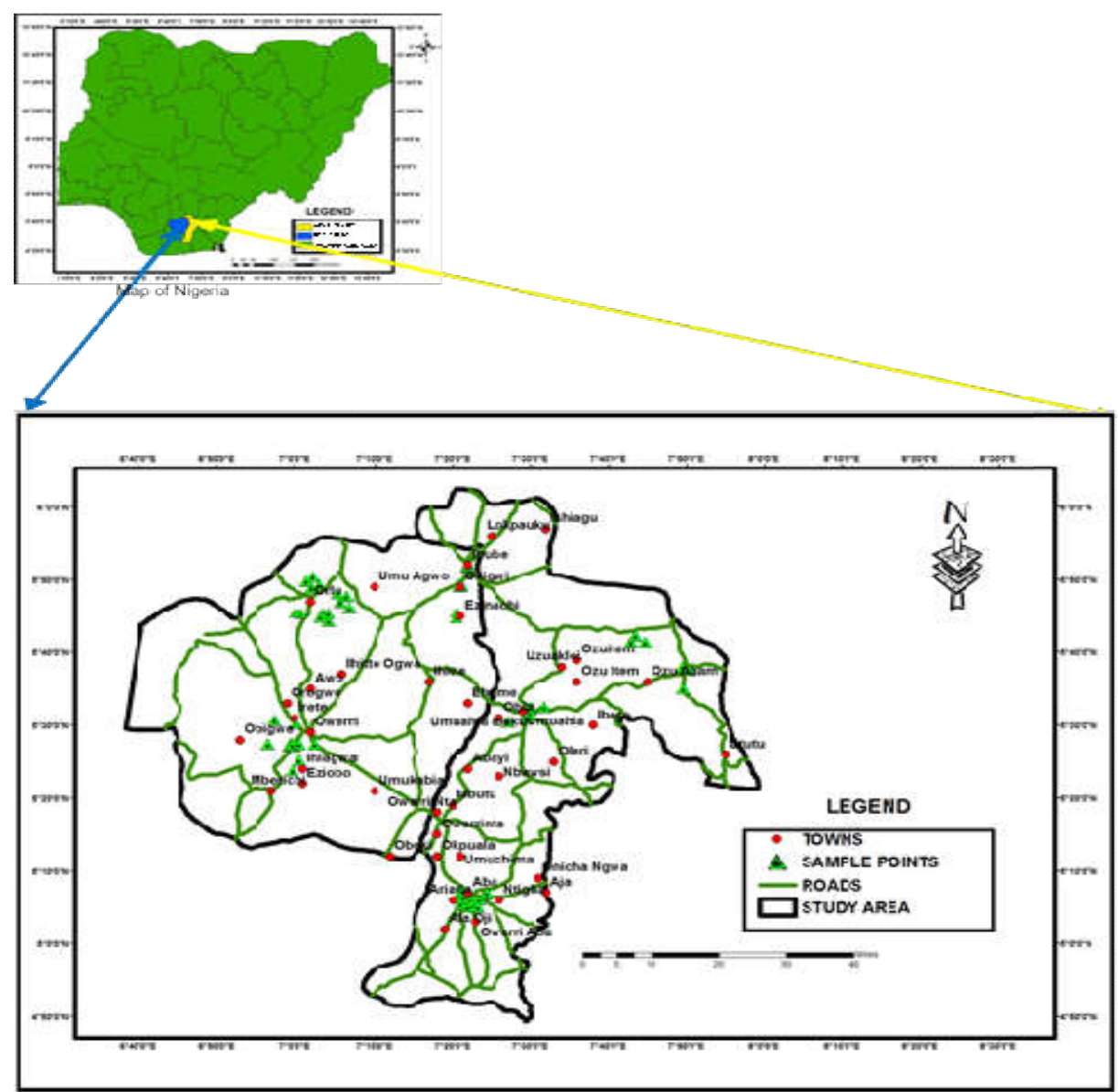

Figure 1. Map of Abia states in the southeast geopolitical zone of Nigeria showing sample sites.

Sample collection and preservation

To ensure representative sampling, different fruit bodies of Pleurotus tuber-regium were sampled from each sampling site around mechanic villages in Abia central senatorial zone of South-eastern Nigeria. Overall, a total of 21 fruiting bodies ( 3 specimens for each site) and the corresponding substrates $(n=21)$ were collected randomly between April and June - 2020. The substrate layers of the deadwood beneath the fruiting bodies were also collected. Only mature and in good condition (free from insect infection) fruiting bodies were selected. Soil debris and 
visible plant matter remaining on the fruiting bodies were cleaned up using a plastic knife. The mushrooms and substrates were dried at room temperature for 6 days. Before analysis, the samples were dried in an oven at $70{ }^{\circ} \mathrm{C}$ for $2 \mathrm{~h}$, allowed to cool and then homogenized to a fine powder and stored in a pre-cleaned polyethylene container [5].

Sample analysis

Digestion of mushroom and substrate samples was performed using an oxi-acidic mixture as described by Nnoron et al. [5]. For the fruiting bodies, $12 \mathrm{~mL}$ of digestion acid mixture $\left(\mathrm{HNO}_{3}\right.$ : $\mathrm{H}_{2} \mathrm{SO}_{4}: \mathrm{H}_{2} \mathrm{O}_{2}$; volume ratio of $\left.2: 1: 1\right)$ was added to $0.5 \mathrm{~g}$ of pulverized sample in a $100 \mathrm{~mL}$ beaker and placed on a temperature-regulated hot plate. Samples were digested at $150{ }^{\circ} \mathrm{C}$ for 3 h. For each soil substrate samples (The soil in which the mushroom developed), $12 \mathrm{~mL}$ of aqua regia was added to $0.5 \mathrm{~g}$ of the sample and digested at $100{ }^{\circ} \mathrm{C}$ for $1 \mathrm{~h}$. The quantification of the metals ( $\mathrm{As}, \mathrm{Cd}, \mathrm{Fe}$ and $\mathrm{Pb}$ ) was performed using Graphite Furnace Atomic Absorption Spectrophotometer (GF-AAS) (Thermo Fisher Scientific iCE3000, USA). Measurement of Hg was done using PE-1000 Nippon analyser, Cold Vapor atomic fluorescence spectrophotometer (CVAFS, America). Three replicates were prepared for each sample, with analytical blanks and standard reference material (Scallops tissue, GBW10024) to be set in the determination process for quality control. The concentration of elements determined in the mushroom and substrate samples are presented in $\mathrm{mg} \mathrm{kg}^{-1}$ dry weight. Certified Reference Material (CRM) for multielement trace analysis - Oriental Basma Tobacco Leaves (INCT-OBTL-5) from the Institute of Nuclear Chemistry and Technology, Dorodna Warsaw Poland was used to check the accuracy and precision of the analytical method. For the Oriental Basma Tobacco Leaves (INCT-OBTL5 ), the recoveries varied from $83 \%$ to $120 \%$. The precision was evaluated based on the standard deviation of the results of triplicate CRM samples. As concerns, the determination of limit of detection (LOD) of the analytical method, 10 reagent blanks were prepared in parallel and analyzed for their metal contents. The standard deviation (SD) of the 10 blanks was calculated and multiplied by three to determine the method detection limit. The limit of quantification, LOQ, was also obtained from triplicate analyses of the blanks (10 times the standard deviation of the replicate analysis).

Determination of $\mathrm{Cd}, \mathrm{Fe}, \mathrm{As}$ and $\mathrm{Pb}$ in mushrooms and soil substrates using graphite furnace atomic absorption spectrometer (GF-AAS)

\section{Instruments and method validation}

Graphite furnace atomic absorption spectrometer interfaced to Spectr AA version 5.1, coupled. with a transversely heated platform atomizer (THPA) was used., The detections were performed at 194.6 and $286.4 \mathrm{~nm}$, field of $0.7 \mathrm{~T}$, and spectral slit width of $0.5 \mathrm{R}$ and 0.5 respectively. Omega platform tube (Agilent Part No. 6310003700) and the PSD-120 autosampler were adopted for THPA, and for sample introduction into the atomizer tube respectively.Argon (Ar) with purity of $99.999 \%$ was used, while peak area was applied exclusively for signal evaluation and quantification. Bulk standard $(30 \mathrm{~mL})$ was prepared by serial dilution from the stock while working standards $(1,3,5$ and $8 \mu \mathrm{g} / \mathrm{L})$ were auto prepared by the equipment. Sample $(30 \mathrm{~mL})$ was injected on 'hot inject' mode, with modifier introduction on 'pre-inject' mode. Method detection limit for $\mathrm{As}$ and $\mathrm{Pb}$ was 0.5 and $0.7 \mu \mathrm{g} / \mathrm{L}$, respectively.

Determination of $\mathrm{Hg}$ using $C V$ - $A F S$

Instrumentation and optimization

Measurement of $\mathrm{Hg}$ was done using PE-1000 Nippon mercury analyser equipped with auto sample changer (HT-300A) and interfaced to PE1000Win version 1.6.4 software. Nippon 
mercury analyser offers a direct sample matrix analysis with patented catalysts and combustion tubes that eliminate external and cumbersome acid/alkali pre-treatment and mercury reduction processes. Same argon purity was used as described above and both Ar and zero air pressures were operated at $0.2 \mathrm{MPa}(29 \mathrm{Psi})$. The equipment was used as recommended by the manufacturer for food sample type, and equipped with auto sampler and operated respectively at low and high modes [2]. A running analytical control and assurance quality (AC/AQ) was performed through the analysis of blank samples and certified reference materials produced by the Institute of Nuclear Chemistry and Technology, Warsaw, Poland. The declared content of $\mathrm{Hg}$ for material INCT-OBTL-5 (Oriental Basma Tobacco Leaves) is $0.021 \pm 0.001 \mathrm{mg} \mathrm{kg}^{-1}$, and our result $(\mathrm{n}=21)$ was $0.019 \pm 0.001 \mathrm{mg} \mathrm{kg}$. The limit of detection (LOD) of this study was $0.003 \mathrm{mg} \mathrm{kg}^{-1}$, and the quantification limit (LOQ) was $0.005 \mathrm{mg} \mathrm{kg}^{-1}$. One blank sample and one certified reference material sample were examined with each set of three to six samples studied.

\section{Sample analysis}

Ten milligrams per litre (10 mg/L) L-cysteine (as stabilizer) prepared in $2 \% \mathrm{HNO}_{3}$ was used to prepare $10 \mu \mathrm{g} / \mathrm{L} \mathrm{Hg}$ standard. Working standards $(0.05,0.10,0.20$ and $0.50 \mathrm{ng})$ were auto made by injecting $5,10,20$ and $50 \mu \mathrm{L}$ of $10 \mu \mathrm{g} / \mathrm{L} \mathrm{Hg}$ standard. Sample $(200 \mu \mathrm{L})$ was auto injected into the sample heating section and decomposed using appropriate setting (furnace/catalyst temperature, time, gas flow). Mercury was atomized in the catalytic section, then collected and concentrated in the form of gold amalgam in the $\mathrm{Hg}$ collection section. The $\mathrm{Hg}$ was then released and atomized again through the $\mathrm{Hg}$ collection section being heated and detected using the atomic fluorescence spectroscopy at a wavelength of $253.7 \mathrm{~nm}$.

\section{Evaluation of mushrooms' mineral bioaccumulation potential}

The ability of the mushrooms to take up and accumulate the elements in fruiting bodies was evaluated by calculating the bioaccumulation factor (BCF) which is the quotient of the element concentration in fruiting bodies to that of the substrates [24]:

$\mathrm{BCF}=\frac{\text { Concentration of element in mushroom fruiting bodies }}{\text { Concentration of element in the substrate }}$

$\mathrm{BCF}$ is a unit less parameter and is calculated as a quotient to the concentration of the metal determined in fruiting body or its morphological part in relation to metal concentration of the substratum in which the mycelium lives (soil, wood, compost) -all analytical data are expressed on a dry weight basis. For BCF values $>1$, the element is accumulated by the mushroom while elements with $\mathrm{BCF}<1$ are considered to be bioexcluded [16].

Estimation of weekly intake (EWI)

The EWI was calculated to estimate the potential hazard from the consumption of a meal of mushrooms using the formula:

$\mathrm{EWI}=\frac{\mathrm{Mc} \times \text { Consumptionrate }}{\text { bodyweight }}$

where $\mathrm{Mc}$ is the metal content of the mushroom ( $\mathrm{mg} \mathrm{kg}^{-1}$, fresh weight), the consumption rate of $100 \mathrm{~g} \mathrm{week}^{-1}$ and $300 \mathrm{~g} \mathrm{week}^{-1}$ for an average level consumer (ALC) and a high-level consumer (HLC), respectively, while the bodyweight for ALC was $30 \mathrm{~kg}$ and that of HLC is $70 \mathrm{~kg}$ according to [25]. The results were interpreted in terms of the (FAO/WHO) provisional tolerable weekly intake for metals [26]. 


\section{Potential health risk assessment}

To evaluate long-term potential health risks associated with trace metal intakes from consumption of these mushroom, the target hazard quotients (THQ) was calculated to evaluate the non-carcinogenic health risk. The THQ is often used in evaluating potential risks from heavy metals consumption from contaminated food. According to Falandysz [24], THQ values greater than 1 show a likelihood to expose the consumer to risks that could result in harmful effects. In this study, non-cancer risk assessment of trace metal exposure from consumption of mushroom was evaluated based on the use of THQ which is a ratio between the estimated dose of contaminant metals and the reference dose below which there will not be any appreciable risk. The method used for the evaluation of THQ is described by the equation below [25].

$\mathrm{THQ}=\frac{\left(\mathrm{M}_{\mathrm{c}} \times \mathrm{IR} \times \mathrm{EF} \times \mathrm{ED} \times 10^{3}\right)}{(\mathrm{RfD} \times \mathrm{BW} \times \mathrm{ATn})}$

where THQ is for non-carcinogenic risk, $\mathrm{M}_{\mathrm{C}}$ is the metal concentration in mushroom $\left(\mathrm{mg} \mathrm{kg}^{-1}\right.$ dry weight). IR is the mushroom ingestion rate ( $\mathrm{g} /$ person/day), assuming $0.5 \mathrm{~g}$ for an ALC (children), and $1.0 \mathrm{~g}$ for an HLC (adults). EF is the exposure frequency (365/days/year). ED is the exposure duration (70 years), equivalent to the average lifetime [5]. RfD is the reference dose of individual metal As (0.003), Cd (1.00), Fe (7.00), $\mathrm{Hg}(0.0005), \mathrm{Pb}(0.00035)\left(\mathrm{mg} \mathrm{kg}^{-1} /\right.$ day) [30]. BW is an average body weight of $70 \mathrm{~kg} \mathrm{HLC}$ and $30 \mathrm{~kg}$ for ALC, according to [27]. ATn is the average exposure time for non-carcinogens (365 days/year $\times$ ED). An index of more than 1 is considered not safe [27] indicating a likely negative impact on the consumers' health. The higher the THQ, the higher the chances of risk to the consuming population. The calculation formula of HI was listed as follows [28]:

$\mathrm{HI}=\mathrm{THQ}_{\mathrm{Pb}}+\mathrm{THQ}_{\mathrm{Cd}}+\mathrm{THQ}_{\mathrm{Fe}}+\mathrm{THQ}_{\mathrm{Hg}}+\mathrm{THQ}_{\mathrm{As}}$

Statistical analysis

Descriptive statistics were performed on data obtained from all samples and one-way analysis of variance (ANOVA) was equally conducted and the result showed that the mean concentration of PAHs in different water sources was statistically significant $(p<0.05)$. Microsoft Office Professional Plus 2016 was used for all data processing, Statistical Package for Social Sciences $\left(\mathrm{SPSS}^{\circledR}\right.$ ) version 16 (SPSS Inc., USA) and STATISTICA ${ }^{\circledR}$ version 10.

\section{RESULT AND DISCUSSION}

\section{Metal contents of mushroom fruiting body and the substrate}

The mean concentrations of five trace metals $(\mathrm{Cd}, \mathrm{Pb}, \mathrm{Fe}, \mathrm{Hg}$ and $\mathrm{As})$ in Pleurotus tuber-regium and its substrate are given in Table 1. All metal concentrations were determined on a dry weight basis in $\mathrm{mg} \mathrm{kg}^{-1}$. Among the investigated five trace metals, all were found to be above the method detection limit. The metal contents varied across the locations. The variations could be a result of differences in substrate composition which is determined by the ecosystem as well as the differences in the absorption of individual metals by the mushroom species and also the age of the mushroom fruiting body or its size plays an insignificant role in the accumulation of trace metals by mushrooms [5]. Lead poisoning has been described to give rise to health disorders like sleeplessness, tiredness, hearing, and weight loss [29]. In pregnancy, lead poisoning has been associated with severe maternofoetal consequences. High levels of lead have a significant potential of increasing maternofoetal and neonatal morbi-mortality [30]. High maternal lead 
levels have been significantly associated with pregnancy hypertension, spontaneous abortion, restricted foetal growth and reduced offspring neurobehavioral development [31-32]. The WHO established a maximum permissible level of $10.0 \mathrm{mg} \mathrm{kg}-1$ for $\mathrm{Pb}$ in raw plant materials [33]. $\mathrm{Pb}$ was detected both in the fruiting body and substrate of the mushroom samples with varying concentrations. Ohiya site 3 contained the highest amount $\left(1.23 \pm 0.06 \mathrm{mg} \mathrm{kg}^{-1}\right)$ of $\mathrm{Pb}$ while the least concentration was exhibited from Olokoro sample $\left(0.21 \pm 0.02 \mathrm{mg} \mathrm{kg}^{-1}\right)$ (Table 1). The mean concentration of $\mathrm{Pb}$ in Ohiya site 3 substrate was the highest $\left(1.26 \pm 0.06 \mathrm{mg} \mathrm{kg}^{-1}\right)$ and least in Olokoro $\left(0.23 \pm 0.03 \mathrm{mg} \mathrm{kg}^{-1}\right)$.

Table 1. Summary of metal contents of Pleurotus tuber-regium fruity body and substrate around automobile workshops in Abia state $\left(\mathrm{mg} \mathrm{kg}^{-1}\right)$.

\begin{tabular}{|l|c|c|c|c|c|c|c|c|c|c|}
\hline \multirow{2}{*}{$\begin{array}{l}\text { Mushroom } \\
\text { species }\end{array}$} & \multicolumn{9}{|c|}{ Fruity Body } & $\mathrm{Fubstrate}$ \\
\hline & $\mathrm{Pb}$ & $\mathrm{Cd}$ & $\mathrm{Fe}$ & $\mathrm{Hg}$ & $\mathrm{As}$ & $\mathrm{Pb}$ & $\mathrm{Cd}$ & $\mathrm{Fe}$ & $\mathrm{Hg}$ & $\mathrm{As}$ \\
\hline Ohiya site 1 & $1.21 \pm 0.08$ & $0.34 \pm 0.06$ & $98.17 \pm 3.08$ & $0.011 \pm 0.003$ & $0.31 \pm 0.04$ & $1.23 \pm 0.06$ & $0.37 \pm 0.08$ & $98.23 \pm 2.69$ & $0.013 \pm 0.004$ & $0.32 \pm 0.11$ \\
\hline Ohiya site 2 & $0.32 \pm 0.03$ & $0.10 \pm 0.03$ & $72.11 \pm 2.04$ & $0.021 \pm 0.006$ & $0.51 \pm 0.06$ & $0.34 \pm 0.03$ & $0.12 \pm 0.03$ & $74.05 \pm 4.07$ & $0.022 \pm 0.003$ & $0.53 \pm 0.06$ \\
\hline Ohiya site 3 & $1.23 \pm 0.06$ & $0.21 \pm 0.02$ & $68.33 \pm 3.10$ & $0.018 \pm 0.008$ & $0.42 \pm 0.04$ & $1.26 \pm 0.06$ & $0.25 \pm 0.06$ & $71.12 \pm 5.02$ & $0.020 \pm 0.003$ & $0.45 \pm 0.10$ \\
\hline Nkwoegwu & $1.10 \pm 0.08$ & $0.11 \pm 0.03$ & $81.51 \pm 2.81$ & $0.012 \pm 0.003$ & $0.26 \pm 0.03$ & $1.14 \pm 0.04$ & $0.13 \pm 0.03$ & $86.06 \pm 2.08$ & $0.023 \pm 0.014$ & $0.28 \pm 0.06$ \\
\hline Afugiri & $0.81 \pm 0.04$ & $0.12 \pm 0.04$ & $72.18 \pm 3.62$ & $0.015 \pm 0.004$ & $0.36 \pm 0.03$ & $0.83 \pm 0.03$ & $0.14 \pm 0.03$ & $92.02 \pm 2.54$ & $0.016 \pm 0.012$ & $0.38 \pm 0.10$ \\
\hline Olokoro & $0.21 \pm 0.02$ & $0.07 \pm 0.03$ & $67.05 \pm 2.08$ & $0.014 \pm 0.006$ & $0.32 \pm 0.04$ & $0.23 \pm 0.03$ & $0.08 \pm 0.02$ & $68.18 \pm 2.40$ & $0.015 \pm 0.003$ & $0.33 \pm 0.06$ \\
\hline Ubakala & $0.42 \pm 0.03$ & $0.05 \pm 0.02$ & $62.16 \pm 1.35$ & $0.009 \pm 0.003$ & $0.24 \pm 0.02$ & $0.46 \pm 0.02$ & $0.07 \pm 0.02$ & $62.06 \pm 1.05$ & $0.010 \pm 0.004$ & $0.26 \pm 0.10$ \\
\hline
\end{tabular}

The concentrations of $\mathrm{Pb}$ found in the substrate samples for Pleurotus tuber-regium are comparable. The content of lead in mushroom samples have been widely reported in the literature: $0.75-7.77 \mathrm{mg} \mathrm{kg}^{-1}$ [34], 0.40-2.80 mg kg${ }^{-1}$ [35], 0.82-1.99 $\mathrm{mg} \mathrm{kg}^{-1}$ [5], $2.40 \mathrm{mg} \mathrm{kg}^{-1}$ [3]. The tolerable weekly intake of lead according to FAO/WHO [28] is $0.025 \mathrm{mg} \mathrm{kg}^{-1}$ body weight.

The concentrations of cadmium $(\mathrm{Cd})$ in the $P$. tuber-regium and substrate are shown in Table 1. The highest concentration of Cd was seen in Ohiya site $1\left(0.51 \pm 0.06 \mathrm{mg} \mathrm{kg}^{-1}\right)$ as compared to Ubakala which recorded a concentration of $0.05 \pm 0.02 \mathrm{mg} \mathrm{kg}^{-1}$. The content of Cadmium in mushroom samples has been reported to be in the ranges of: $0.81-7.50 \mathrm{mg} \mathrm{kg}{ }^{-1}$ [36], $3.37 \mathrm{mg} \mathrm{kg}^{-1}$ [37], $1.99 \mathrm{mg} \mathrm{kg}^{-1}$ [5]. The findings of this study are therefore in good agreement with the results reported from similar studies. The European Commission sets a limit for $\mathrm{Cd}$ of $0.2 \mathrm{mg} \mathrm{kg}^{-1}$ wet weight. Cadmium has been reported as the most deleterious among the heavy metals measured in mushrooms [38]. According to the WHO the maximum permissible levels in raw plant materials for cadmium is set at $0.30 \mathrm{mg} \mathrm{kg}^{-1}$ [33]. Clearly, all the values recorded are above this permissible limit.

The Fe content of the investigated mushroom samples of this study ranged from $68.33 \pm 3.10$ $\mathrm{mg} \mathrm{kg}^{-1}$ in Ohiya site 3 to $98.17 \pm 3.08 \mathrm{mg} \mathrm{kg}^{-1}$ in ohiya site 1 (Table 1). The analysed mushroom samples had an average Fe concentration of $81.51 \pm 2.81 \mathrm{mg} \mathrm{kg}-1$, which was above the safe limit of $15 \mathrm{mg} \mathrm{kg}^{-1}$ set by WHO [33] while substrate Fe content ranged from $62.06 \pm 1.05 \mathrm{mg} \mathrm{kg}^{-1}$ from Ubakala to $98.23 \pm 2.69 \mathrm{mg} \mathrm{kg}^{-1}$ from Ohiya site 1 . According to findings in publications until 1999, reported Fe content of mushrooms was found to vary between 30.0 and $150.0 \mathrm{mg}$ $\mathrm{kg}^{-1}$ [12]. Similarly, Fe contents in mushroom samples, over the recent years, have been reported in the range of 101.6-543.8 mg kg${ }^{-1}$ [20], 1322.4-1596.0 mg kg${ }^{-1}$ [38], 43.7-65.1 mg kg ${ }^{-1}$ [39], $44.4-125.1 \mathrm{mg} \mathrm{kg}^{-1}$ [40], and $8.25-58.25 \mathrm{mg} \mathrm{kg}^{-1}$ [29], 74.08-123.40 mg kg-1 [5]. This difference of results over the years could be due to increased use of iron, associated with increased automobile repairs. Thus, the concentration of iron reported in this study, are in line with values reported in previous studies. The adequate intake of iron in the diet is indispensable in improving blood iron stores thereby limiting the likelihood of anemia [41].

The $\mathrm{Hg}$ content of the mushrooms studied, in the present work, was found to vary from $0.011 \pm 0.003 \mathrm{mg} \mathrm{kg}^{-1}$ from Ubakala to $0.021 \pm 0.006 \mathrm{mg} \mathrm{kg}^{-1}$ in Ohiya site 2 (Table 1). The average $\mathrm{Hg}$ content of the analyzed samples was $0.016 \mathrm{mg} \mathrm{kg}^{-1}$. Usual $\mathrm{Hg}$ content in mushrooms varies between 0.065 and $0.24 \mathrm{mg} \mathrm{kg}^{-1}$ [24]. Similar earlier studies have also indicated $\mathrm{Hg}$ contents in the mushroom samples vary as follow: $0.56 \mathrm{mg} \mathrm{kg}^{-1}$ [42] $0.068-0.14 \mathrm{mg} \mathrm{kg}^{-1}$ [16]. 
Concentrations of $\mathrm{Hg}$ determined, in this study, are also in good agreement with the results reported in the literature. As contents of $P$. tuber-regium and substrates ranged from 0.24 to 0.51 $\mathrm{mg} \mathrm{kg}^{-1}$ and $0.26-0.53 \mathrm{mg} \mathrm{kg}^{-1}$, respectively. No significant difference was observed between sites. The highest mean contents of As was observed in Pleurotus tuber-regium from Ohiya site 3 with $\left(0.42 \mathrm{mg} \mathrm{kg}^{-1}\right)$. Accumulation of As in Ohiya sites can be attributed to environmental factor [43]. These data were in the range of As concentrations reported for mushrooms and they are below the WHO permissible limits in foods, which is $3 \mathrm{mg} \mathrm{kg}^{-1}$. Before now there are no reports of As in Pleurotus tuber-regium from southeastern Nigeria.

The discrepancies in the reported values in the present study as compared to the findings of similar surveys can be attributed to various factors such as the analytical methods used, and the substrate on which they grew. Mushrooms exhibit a very effective mechanism that promotes the uptake of heavy metals from the environment in which they grow [44]. Environmental and fungal factors seem to affect the accumulation of trace metals in mushrooms. These environmental factors include organic matter content, $\mathrm{pH}$ and metal concentration in the substrate while fungal factors include the species, developmental stages, intervals between fructifications and biochemical composition, age of the mycelium. These factors contribute significantly to determining the amount of heavy metals in the mushroom samples [20].

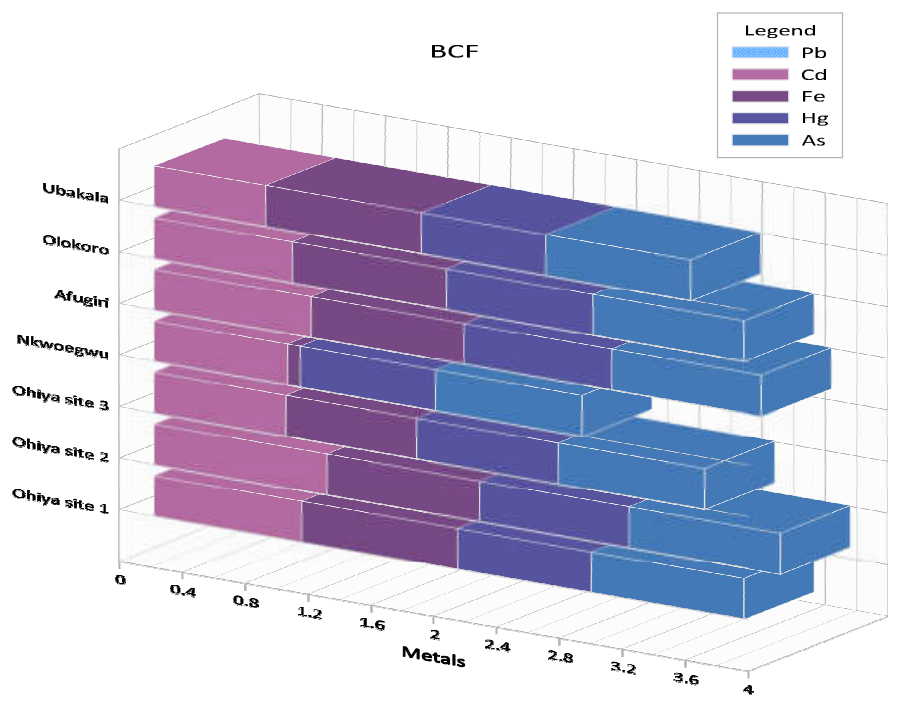

Figure 2. Mean values of BCFs of metals.

\section{The bioaccumulation factor}

The bioconcentration factor (BCF) or transfer factor (TF) evaluates the capacity of the mushrooms to accumulate in fruiting bodies these trace metals from the substrates on which they grow. This factor is usually expressed as the ratio of the content of the heavy metal in the fruiting body of the mushroom to the content in the underlying substrate (both in dry matter). The coefficient of the BCF of the heavy metals is calculated using equation 1: The highest BCF values are 1.02 from Ohiya site 1, 1.04 from Ohiya site 2 and 1 from Afugiri. The corresponding results are shown in Figure 2. The bio-accumulation factors of metals reported in this study are comparable with those reported in the literature [5, 41]. While $\mathrm{Cd}$ and $\mathrm{Pb}$ accumulate at higher ratios in the mushrooms, the other elements accumulate with relatively lesser ratios. 


\section{Estimated metal intakes}

Provisional tolerable weekly intake (PTWI) is defined as the maximum quantity of contaminants that a consumer weighing 60-70 kg may take per week [30]. The EWI of Pb, Cd, Fe, $\mathrm{Hg}$ and $\mathrm{As}$ of $100 \mathrm{~g} \mathrm{week}^{-1}$ and $300 \mathrm{~g}$ week $^{-1}$ for ALC and a HLC, respectively, while the body weight for ALC was $30 \mathrm{~kg}$ and that of HLC is $70 \mathrm{~kg}$ of mushroom per week compared to the PTWI values. The estimated weekly intake of $\mathrm{Fe}, \mathrm{Pb}, \mathrm{Cd}, \mathrm{Hg}$ and $\mathrm{As}$ from consumption of the studied mushrooms are lower than the PTWI as shown in Table 2. The estimated intakes are generally below the PTWI values except for Fe. Consequently, there is no toxicological concern over these trace metal intakes from the consumption of mushrooms investigated in this study.

Table 2. Estimated mineral dietary intakes from mushroom consumption $(\mu \mathrm{g} / \mathrm{kg}$ bw/week).

\begin{tabular}{|c|c|c|c|c|c|c|}
\hline \multirow{2}{*}{$\begin{array}{l}\text { Mushroom } \\
\text { species }\end{array}$} & \multicolumn{6}{|c|}{ EWI } \\
\hline & Lc & $\mathrm{Pb}$ & $\mathrm{Cd}$ & $\mathrm{Fe}$ & $\mathrm{Hg}$ & As \\
\hline \multirow[t]{2}{*}{ Ohiya site 1} & ALC & 4.03 & 1.70 & $* 327$ & 0.04 & 1.03 \\
\hline & HLC & 5.19 & 2.20 & $* 420$ & 0.05 & 1.33 \\
\hline \multirow[t]{2}{*}{ Ohiya site 2} & ALC & 1.06 & 0.33 & $* 240$ & 0.07 & 1.70 \\
\hline & HLC & 1.37 & 0.43 & *309 & 0.09 & 2.19 \\
\hline \multirow{2}{*}{ Ohiya site 3} & ALC & 4.10 & 0.70 & $* 227$ & 0.06 & 1.40 \\
\hline & HLC & 5.27 & 0.90 & $* 292$ & 0.08 & 1.80 \\
\hline \multirow{2}{*}{ Nkwoegwu } & ALC & 3.67 & 0.37 & $* 227$ & 0.04 & 0.87 \\
\hline & HLC & 4.71 & 0.47 & *349 & 0.05 & 1.11 \\
\hline \multirow{2}{*}{ Afugiri } & ALC & 2.70 & 0.40 & $* 240$ & 0.05 & 1.20 \\
\hline & HLC & 3.47 & 0.51 & *309 & 0.06 & 1.54 \\
\hline \multirow{2}{*}{ Olokoro } & ALC & 0.70 & 0.23 & $* 223$ & 0.05 & 1.07 \\
\hline & HLC & 0.90 & 0.30 & $* 287$ & 0.06 & 1.37 \\
\hline \multirow{2}{*}{ Ubakala } & ALC & 1.40 & 0.17 & $* 207$ & 0.04 & 1.8 \\
\hline & HLC & 1.80 & 0.21 & $* 366$ & 0.05 & 1.03 \\
\hline \multicolumn{2}{|l|}{ PTWI } & 25.0 & 7.00 & 17.0 & 5 & 14.9 \\
\hline
\end{tabular}

*Exceed the PTWI limit.

\section{Target hazard quotient (THQ)}

The THQ has been accepted as a parameter for risk assessment of metals associated with the intake of contaminants from foodstuff. It symbolizes the ratio between the estimated dose of a contaminant and the reference dose below which there will be no appreciable risk. The THQ values were evaluated based on the consumption of mushroom meal by an ALC who consumes $0.5 \mathrm{~g}$ of mushroom from a meal and an HLC who consumes $1.0 \mathrm{~g}$ of mushroom from a meal using the mean concentration of data obtained. Thus, trace metal concentrations of mushroom species were used for the calculation of THQ for the close populations (Table 3). The mean metal concentration was used for calculation of THQ. The THQ values of $\mathrm{Pb}, \mathrm{Hg}$ and As were less than 1 in all mushroom species and indicated that there is no health risk to humans.

However, the $\mathrm{Cd}$, and Fe showed a higher value $(>1)$ in different species, which signifies that the level of exposure is higher than the reference dose and therefore, it assumes that a daily exposure at this level is likely to cause adverse health effects during a lifetime in a human population [14].

The total hazard index of easy trace metals was also evaluated in mushroom species. In the current scenario, the total HIs varied from 1.325 to 3.441 , respectively. Among all the investigated trace metals, the mushroom contaminated by $\mathrm{Pb}$, and $\mathrm{Cd}$ had relatively higher potential health risks, particularly for the adults. The HI is the sum of all measured hazard quotient. When the hazard index exceeds unity, there may be concern about potential health 
effects. THQ $>1$ means that the risk level is lower than the oral reference dose (RfD), but daily metal exposure at this stage is expected to be incredible to pose any negative impact during an individual lifetime.

Table 3. THQ and HI values for non-carcinogenic effect from mushroom consumption.

\begin{tabular}{|c|c|c|c|c|c|c|c|}
\hline \multirow{2}{*}{ Sites } & \multicolumn{7}{|c|}{ THQ/HI } \\
\hline & Lc & $\mathrm{Pb}$ & $\mathrm{Cd}$ & $\mathrm{Fe}$ & $\mathrm{Hg}$ & As & HI \\
\hline \multirow[t]{2}{*}{ Ohiya site 1} & ALC & 0.26 & 0.02 & 1.23 & 0.002 & 0.21 & 1.722 \\
\hline & HLC & 0.43 & 0.04 & 1.53 & 0.004 & 0.47 & 2.474 \\
\hline \multirow[t]{2}{*}{ Ohiya site 2} & ALC & 0.22 & 0.20 & 0.45 & 0.035 & 0.42 & 1.325 \\
\hline & HLC & 0.41 & 0.47 & 1.13 & 0.063 & 0.72 & 2.793 \\
\hline \multirow{2}{*}{ Ohiya site 3} & ALC & 0.43 & 0.93 & 0.95 & 0.026 & 0.27 & 2.606 \\
\hline & HLC & 0.82 & 1.05 & 1.08 & 0.041 & 0.45 & 3.441 \\
\hline \multirow{2}{*}{ Nkwoegwu } & ALC & 0.36 & 0.43 & 0.47 & 0.032 & 0.30 & 1.592 \\
\hline & HLC & 0.61 & 0.94 & 0.82 & 0.051 & 0.65 & 3.071 \\
\hline \multirow{2}{*}{ Afugiri } & ALC & 0.23 & 0.78 & 0.80 & 0.061 & 0.51 & 2.381 \\
\hline & HLC & 0.51 & 1.05 & 1.14 & 0.083 & 0.71 & 3.493 \\
\hline \multirow{2}{*}{ Olokoro } & ALC & 0.32 & 0.28 & 0.62 & 0.031 & 0.41 & 1.661 \\
\hline & HLC & 0.62 & 0.43 & 1.01 & 0.063 & 0.91 & 3.033 \\
\hline \multirow{2}{*}{ Ubakala } & ALC & 0.31 & 0.87 & 0.36 & 0.022 & 0.24 & 1.802 \\
\hline & HLC & 0.68 & 1.06 & 0.73 & 0.044 & 0.52 & 3.034 \\
\hline
\end{tabular}

\section{CONCLUSIONS}

This study filled some information gaps on the mineral contents of Pleurotus tuber-regium in southeastern Nigeria and is the first time that data on As in these mushrooms are presented for this region. The mean concentrations of trace metals $(\mathrm{Pb}, \mathrm{Cd}, \mathrm{Fe}, \mathrm{Hg}$ and $\mathrm{As})$ obtained in this study showed different accumulation patterns in mushrooms. The BCF values of trace metals in mushrooms indicated that $\mathrm{Cd}$ has the highest value, followed by $\mathrm{Pb}$, which may pose a risk to human health. According to the THQ calculations, mercury did not pose any risk on human health, whereas, the other determined trace metals gave THQ values of $1<$ THQ $<10$ and could cause risk in the long term. The EWI was found to be lower than PTWI for all toxic elements studied. Nevertheless, it should be considered that regular or excessive consumption of mushrooms could exceed the recommended intake for lead and cadmium. It can be concluded that automobile repair activities contributed to the high levels of trace metals in the soil. The effluents from the mechanic village should be properly treated and disposed of using environmentally friendly practices that comply with regulatory standards and guidelines. This study gives a brief insight into the current scenario of mushrooms contamination and possible future human health risk estimates.

\section{ACKNOWLEDGEMENTS}

The authors acknowledge the technical assistance of Prof. Loai Aljerf of the Department of Life Sciences, Faculty of Dentistry, University of Damascus, Syria; Dr. Ewuzie Ugochukwu from Escravos Gas-to-Liquid Laboratory Warri, Delta State, Nigeria and National Association of Nigerian Automobile workers for their assistance and permission to use the sample sites.

\section{REFERENCES}

1. Barros, L.; Venturini, B.A.; Baptista, P.; Estevinho, L.M.; Ferreira, I.C.F.R. Chemical composition and biological properties of Portuguese wild mushrooms: A comprehensive study. J. Agric. Food Chem. 2008, 56, 3856-2862. 
2. Falandysz, J.; Mędyk, M.; Saba, M.; Zhang, J.; Wang, Y.; Li, T. Mercury in traditionally foraged species of fungi (macromycetes) from the karst area across Yunnan province in China. Appl. Microbiol. Biotechnol. 2020, 104, 9421-9432.

3. Gründemann, C.; Reinhardt, J.K.; Lindequist, U. European medicinal mushrooms: Do they have potential for modern medicine? - An update. Phytomedicine 2020, 66, 153131. https://doi.org/10.1016/j.phymed.2019.153131

4. Agrahar-Murugkar, D.; Subbulakshmi, G. Nutritional value of edible wild mushrooms collected from the Khasi Hills of Meghalaya. Food Chem. 2005, 89, 599-603.

5. Nnorom, I.C.; Eze, S.O.; Ukaogo, P.O. Mineral contents of three wild-grown edible mushrooms collected from forests of southeastern Nigeria: An evaluation of bioaccumulation potentials and dietary intake risks. Sci. Afr. 2020, https://doi.org/10.1016/j.sciaf.2019.e00163.

6. Odjegba, V.J.; Sadiq, A.O. Effects of spent engine oil on the growth parameters, chlorophyll and protein levels of Amaranthus hybridus L. Environmentalist 2002, 22, 23-28.

7. Obini, U.; Okafor, C.O.; Afiukwa, J.N. Determination of levels of polycyclic aromatic hydrocarbons in soil contaminated with spent motor Engine oil in Abakaliki Auto-Mechanic Village. J. Appl. Sci. Environ. Manage. 2013, 17, 169-175.

8. Sharifi, M.; Sadeghi, Y.; Akbarpour, M. Germination and growth of six plant species on contaminated soil with spent oil. Inter. J. Environ. Sci. Technol. 2007, 4, 463-470.

9. Ipeaiyeda, A.R.; Dawodu, M. Heavy metals contamination of topsoil and dispersion in the vicinities of reclaimed auto-repair workshops in Iwo, Nigeria. Bull. Chem. Soc. Ethiop. 2008, 22, 339-348.

10. Sesli, E.; Tuzen, M.; Soylak, M. Evaluation of trace metal contents of some wild edible mushrooms from Black Sea region, Turkey. J. Hazard. Mater. 2008, 160, 462-467.

11. Falandysz, F.; Saba, M.; Strumińska-Parulska, D. ${ }^{137}$ Caesium, ${ }^{40} \mathrm{~K}$ and total $\mathrm{K}$ in Boletus edulis at different maturity stages: Effect of braising and estimated radiation dose intake, Chemosphere 2021, 268, 129336. https://doi.org/10.1016/j.chemosphere.2020.129336.

12. Fernandes, A.; Jerzy Falandysz, J.; Siric, I. The toxic reach of mercury and its compounds in human and animal food webs. Chemosphere. 2020, 261, 127765.

13. Falandysz, J. Mercury bio-extraction by fungus Coprinus comatus: A possible bioindicator and mycoremediator of polluted soils? Environ. Sci. Pollut. Res. Int. 2016, 23, 7444-7451.

14. Olusegun, V.O. Medicinal uses of mushrooms in Nigeria: towards full and sustainable exploitation, Afr. J. Trad. Complement. Altern. Med. 2011, 8, 267-274.

15. Nnorom, I.N. Lead and copper contents of the sclerotium of the mushroom Pleurotus tuberregium (Osu): Assessment of contribution to dietary intake in southeastern Nigeria. Toxicol. Environ. Chem. 2011, 93, 1359-1367.

16. Nnorom, I.C.; Jarzynska, G.; Falandysz, J.; Drewnowska, M.; Okoye, I.; Oji-Nnorom, C.G. Occurrence and accumulation of mercury in two species of wild grown Pleurotus mushrooms from south eastern Nigeria. Ecotox. Environ. Safety 2012, 84, 78-83.

17. Nnorom, I.C.; Jarzynska, G.; Drewnowska, M.; Kojta, A.; Pankavec, S.; Falandysz, J. Major and trace elements in sclerotium of Pleurotus tuber-regium (Ósu) mushroom - dietary intake and risk in southeastern Nigeria. J. Food Comp. Anal. 2013, 29, 73-81.

18. Saba, M.; Falandysz, J.; Nnorom, I.C. Evaluation of vulnerability of Suillus variegatus and Suillus granulatus mushrooms to sequester mercury in fruiting bodies. J. Environ. Sci. Health Part B 51 2016, doi:10.1080/03601234.2016.1170552.

19. Komorowicz, I.; Hanc, A.; Lorenc, W.; Barałkiewicz, D.; Falandysz , J.; Wang, Y. Arsenic speciation in mushrooms using dimensional chromatography coupled to ICP-MS detector. Chemosphere 2019, 233, 223-233.

20. Drewnowska, M.; Falandysz, J.; Chudzińska, M.; Hanć, A.; Saba, M.; Barałkiewicz, D. Leaching of arsenic and sixteen metallic elements from Amanita fulva mushrooms after food processing. LWT Food Sci. Technol. 2017, 84, 861-866. 
21. Radulescu, C.; Stihi, C.; Busuioc, G.; Popescu, I.V.; Gheboianu, A.I.; Cimpoca, V.G. Evaluation of essential elements and heavy metal levels in fruiting bodies of wild mushrooms and their substrate by EDXRF spectrometry and FAA spectrometry. Rom. Biotech. Lett. 2010, 15, 5444-5456.

22. Falandysz, J.; Dryżałowska, A.; Zhang, J.; Wang, Y. Mercury in raw mushrooms and mushrooms stir-fried in deep oil. J. Food Compos. Anal. 2019, 82, 103239.

23. Nnorom, I.C.; Ewuzie, U.; Eze, S.O. Multivariate statistical approach and water quality assessment of natural springs and other drinking water sources in Southeastern Nigeria. Heliyon 2019, 5, e01123.

24. Falandysz, J.; Kojta A.K.; Jarzyńska, G.; Drewnowska, A.; Dryżałowska, A.; Wydmańska, D.; Kowalewska, I.; Wacko, A.; Szlosowska, M.; Kannan, K.; Szefer, P. Mercury in Bay Bolete Xerocomus badius: Bioconcentration by fungus and assessment of element intake by humans eating fruiting bodies. Food Addit. Contam. Part A 2012, 29, 951-961.

25. Chien, L.C.; Hung, T.C.; Choang, K.Y.; Choang, K.Y.; Yeh, C.Y.; Meng, P.J.; Shieh, M.J.; Han, B.C. Daily intake of TBT, Cu, Zn, Cd and As for fishermen in Taiwan. Sci. Total Environ. 2002, 285, 77-185.

26. Kalac, P. Trace element contents in European species of wild growing edible mushrooms: A review for the period 2000-2009. Food Chem. 2010, 122, 2-15.

27. Ukaogo, P.O.; Aljerf, L.; Obike, A.; Ojah, E.O.; Nwaogwugwu, J.C. Evaluation of physicochemical characteristics and health risk of polycyclic aromatic hydrocarbons in borehole waters around automobile workshops in Southeastern Nigeria. Groundw. Sustain. Dev. 2021, 104-121. https://doi.org/10.1016/j.gsd.2021.100615.

28. Storelli, M.M. Potential human health risks from metals $(\mathrm{Hg}, \mathrm{Cd}$, and $\mathrm{Pb})$ and polychlorinated biphenyls (PCBs) via seafood consumption: estimation of target hazard quotients (THQs) and toxic equivalents (TEQs). Food Chem. Toxicol. 2008, 46, 2782-2788.

29. Udochukwu, U.; Nekpen, B.O.; Udinyiwer, O.C.; Omeje F.I. Bioaccumulation of heavy metals and pollutants by edible mushroom collected from Iselu market, Benin city. Int. J. Curr. Microbiol. Appl. Sci. 2014, 3, 52-57.

30. Hertz-Picciotto, I. Patterns and determinants of blood lead during pregnancy, Am. J. Epidemiol. 2000, 152, 829-837.

31. Bacis, G. Lead poisoning in pregnancy: Prevention and treatment. Clin. Toxicol. 2009, 47, 492-497.

32. Flora, G.; Gupta, D.; Tiwari, A. Toxicity of lead: A review with recent updates, Interdiscip. Toxicol. 2012, 5, 47-58.

33. World Health Organization. Forty fourth report of WHO expert committee on food additives: Evaluation of certain food additives and contaminants, Geneva; 2004, pp 32-34.

34. Tuzen, M.; Ozdemir, M.; Demirbas, A. Study of some heavy metals in some cultivated and cultivated mushrooms of Turkish origin, Food Chem. 1998, 63, 247-251.

35. Svoboda, L.; Kalac, P. Contamination of two edible Agaricus spp. mushrooms growing in a town with cadmium, lead, and mercury. Bull. Environ. Contam. Toxicol. 2003, 71, 123-130.

36. Soylak, M.; Karatepe, A.; Elci, L.; Dogan, M. Column preconcentration/separation and atomic absorption spectrometric determinations of some heavy metals in table salt samples using amberlite XAD-1180. Turk. J. Chem. 2013, 27, 235-242.

37. Pavel, K.; Lubomír, S.; Božena, H. Contents of detrimental metals mercury, cadmium and lead in wild growing edible mushrooms, A review. Energy Educ. Sci. Technol. 2004, 13, 3138 .

38. Naresh, R.M.; Udaya, B.R.E.; Byragi, R.T. Assessment of heavy metal threat in Agaricus bisporus mushrooms cultivated from water hyacinth weed of Kolleru lake, Andhra Pradesh - India. Int. J. Environ. Sci. 2012, 3, 28-35. 
Evaluation of risk caused by intake of trace metal through consumption of P. tuber-regium 241

39. Quarcoo, A.; Adotey. G. Determination of heavy metals in Pleurotusostreatus (Oyster mushroom) and Termitomycesclypeatus (Termite mushroom) sold on selected markets in Accra, Ghana. Mycosph.2013, 4, 960-7.

40. George, P.L.; Ranatunga, T.D.; Reddy, S.S.; Sharma, G.C. A comparative analysis of mineral elements in the mycelia and the fruiting bodies of Shiitake mushrooms. Am. J. Food Technol. 2014, 9, 360-439.

41. Gebrelibanos, M.; Megersa, N.; Taddesse, A.M. Levels of essential and non-essential metals in edible mushrooms cultivated in Haramaya, Ethiopia,.Int. J. Food Cont. 2016, 3, 28-35.

42. Nasr, N.; Malloch, D.W.; Arp, P.A. Quantifying Hg within ectomycorrhizal fruiting bodies, from emergence to senescence. Fungal Biol. 2012, 116, 1163-1177.

43. Gonçalves, J.M.; Monique, D.C.S.; Rafael, C.C.R.; Renata, J.M.; Silvana, C.J. Macro and trace elements in edible mushrooms, Shiitake, Shimeji and Cardoncello from Petrópolis, Rio de Janeiro, Brazil. Ciência Rural. 2014, 44, 943-949.

44. Zhu, F.; Qu, L.; Fan, W.; Qiao, M.; Hao, H.; Wang, X. Assessment of heavy metals in some wild edible mushrooms collected from Yunnan Province, China. Environ. Monit. Assess. 2011, 179, 191-199.

45. Omaka, O.N.; Aghamelu, O.P.; Ike-Amadi, C.A.; Ofoezie, R.C. Assessment of the quality of groundwater from different parts of Southeastern Nigeria for potable use. Environ. Earth Sci. 2017, 76, 344-367. 